${ }^{5}$ KENDELL, R. E. (1987) The future of psychiatric research in Britain. Bethlem \& Maudsley Gazette, 34, 24-25.

${ }^{6} \mathrm{HILL}$, D. (1978) The qualities of a good psychiatrist. British Journal of Psychiatry, 133, 97-105.

'JONEs, K. (1978) Society looks at the psychiatrist. British Journal of Psychiatry, 132, 321-332.

${ }^{8}$ GreBen, S. E. (1987) Psychotherapy today. British Journal of Psychiatry, 151, 283-287.

${ }^{9}$ Kreitman, N. (1962) Psychiatric orientation: A study of attitudes among psychiatrists. Journal of Mental Science, 108, 317-328.
${ }^{10}$ CaIn, T. M. \& SmaIL, D. J. (1979) The Treatment of Mental Illness: Science, Faith and the Human Personality. University of London Press.

"PAllis, D. J. \& StofrelmaYr, B. M. (1973) Social attitudes and treatment orientation among psychiatrists. British Journal of Medical Psychology, 46, 75-81.

${ }^{12}$ Mayou, R. (1987) Burnout. British Medical Journal, 295, 84-85.

${ }^{13}$ Murray, R. M. (1987) Problems plus assets. Bethlem \& Maudsley Gazette, 34, 26.

\title{
Dialogues on Contemporary Issues
}

The British Psycho-analytical Society will be holding a series of dialogues on contemporary issues between distinguished guests and members of the Society at the
Institute of Psycho-Analysis during the Summer Term 1988 from $6.00-7.45 \mathrm{pm}$ on the following dates:

\begin{aligned} & \multicolumn{1}{c}{ Title of Dialogue } \\ May 4 & Society as a Field of Study \\ 11 & Crime and Punishment \\ 18 & Quis Custodiet-Nuclear Disarmament \\ & and the Military Mind \\ 25 & Psychoanalysis and Social Anthropology \\ June 1 & Leadership \\ 8 & The Character of Mind \\ 15 & Art and Psychoanalysis \\ 22 & Tranquility-An Epicurean State of Bliss \\ 29 & Is Depression an Illness? \end{aligned}

Admission by ticket only; fee for each Dialogue is $£ 5$. Applications for tickets, quoting specific dates and enclosing a cheque made payable to the INSTITUTE OF PSYCHOANALYSIS, together with a stamped and self-addressed

\begin{tabular}{|c|c|}
\hline \begin{tabular}{l}
\multicolumn{1}{c}{ Guest } \\
Dr Eric Miller \\
Dr David A. Thomas \\
Air Comm. A. Mackie
\end{tabular} & \begin{tabular}{l}
\multicolumn{1}{c}{ Member } \\
Mrs Isabel Menzies Lyth \\
Dr Nicholas Temple \\
Dr Hanna Segal
\end{tabular} \\
\hline $\begin{array}{l}\text { Dr Audrey Cantlie } \\
\text { Dr John Rae } \\
\text { Mr Colin McGinn } \\
\text { Prof Sir Ernst Gombrich } \\
\text { Prof Myles Burnyeat } \\
\text { Prof Arthur Crisp }\end{array}$ & $\begin{array}{l}\text { Mrs Elizabeth Spillius } \\
\text { Mr Michael Brearley } \\
\text { Dr Dennis Duncan } \\
\text { Prof Joseph Sandler } \\
\text { Dr John Padel } \\
\text { Dr Clifford Yorke }\end{array}$ \\
\hline
\end{tabular}

envelope, should be sent to: The Executive Secretary, Institute of Psycho-Analysis, 63 New Cavendish Street, London WIM 7RD.

\section{The British Neuropsychiatry Association}

The formation of The British Neuropsychiatry Association has been announced with Chairman: Professor W. A. Lishman; Secretary: Dr J. M. Bird; Treasurer: Dr M. Robertson; Committee Members: Dr E. H. Reynolds (neurologist), Dr M. Wyke (neuropsychologist).

The aim of this Association will be to encourage crossdisciplinary discussion of clinical and academic issues of common interest within the fields of neurology, psychiatry and neuropsychology. All interested professionals in those and allied disciplines are warmly invited to join Academic and clinical meetings will be held twice yearly. Subscription rate will be $£ 10$ per annum - to include attendance at and abstracts of those meetings. Cheques, payable to 'The British Neuropsychiatry Association', should be sent to Dr Mary Robertson, Academic Department of Psychiatry, The Middlesex Hospital, London WIN 8AA.

Subscriptions should be sent before 17 June.

The next meeting will be held at the National Hospital, Queen Square, London WCIN 3BG On 8 July 1988. The topic will be 'The Neuropsychiatry of the Frontal Lobes'. Speakers will include: S. Lewis (schizophrenia), C. Binnie (seizures), R. Jacobsen (alcoholism), D. Neary (dementia), J. Bird (personality), A. Lees (Parkinson's disease), E. Taylor (hyperkinesis), R. Passingham (psychology), and T. Robins (neurochemistry).

Further details: Dr J. M. Bird, Burden Neurological Hospital, Stoke Lane, Stapleton, Bristol BS16 1QT. 